\title{
Dogmata which crossed the inter-war publications from Oltenia
}

\author{
Cristina Pretorian ${ }^{1}$, Dan Ionescu ${ }^{2, *}$ \\ ${ }^{1}$ Carol I High School, Craiova, Romania \\ ${ }^{2}$ Nicolae Titulescu High School, Craiova, Romania \\ *E-mail address: jonescus@yahoo.com
}

\begin{abstract}
ABSRACT
The research starts from a previous incidental acknowledgement concerning persisting of certain dogmata in the history of press; it aims to investigate the emergence of the dogmata in inter-war press from Oltenia. Various dogmata crossed inter-war magazines from Oltenia, but they have not been received without analysis. On the contrary, they were exposed as far as serving the publication profile. "Gazzette of the School" received in columns educational ideas of some philosophers and educators fashionable, who have subjected to experiment, their theory. The comparative analysis of Oltenia magazines from monarchical range are detached three dogmata-patterns: antiutilitarianism, Romanism and pedagogical experimental. They are examined the practical effects of these dogmata-patterns.
\end{abstract}

Keywords: journalism; press; journalistic dogmata; Oltenia

\section{INTRODUCTION}

Adopting a doctrine as a debate, is assenting to it perspective. Almost all journalists manifested an exacerbated fear, but justified, beside the threat from the East, of the Communism. The thinkers who not sympathized with socialist-communist utopia breathlessly were immediately agreed and taken as an example of anti-communist reason, as the German philosopher Friedrich Wilhelm Foerster (1869-1966): "is considered one of the greatest contemporary philosophers and educator. His ideas and principles are applied with great ease and effectiveness in education (Ionescu, 2013a; Borowski, 2013a; Vlăduţescu, 2013c). Those relating to moral education were systematized and coagulated into a system, that has been applied to many primary and secondary schools and came to good results as possible" (Gheorghe Ivănescu, teacher degree I, The school seen by the light of the Foerste's concepts, no. 3-4, "Gazzette of the School", 1931).

In 1931, the numbers 3-4 of "Gazzette of the School" GheorgheIvănescu, teacher degree I, published the article entitled School seen by the light ofthe Foerster's concepts: "Foerster is considered one of the greatest contemporary philosophers and educator. His ideas and principles are applied with great ease and effectiveness in education. Those relating to moral education were systematized and coagulated into a system, that has been applied to many primary and secondary schools and came to good results as possible. "

Fr. Foerster, "after the war (World War I, n.n.) was called to Zurich, where he had gone (being in need, being in disgrace because of his pacifist attitude, n.n.), and it was entrusted to a 
chair at Munich", by the level of which has imposed the doctrine that the teacher Gheorghe Ivănescu dares to present it, the two sides, philosophy of system and applied pedagogy (Ionescu, 2013b; Borowski, 2013b).

The first element of philosophy in the discussion, social regeneration, can be achieved recommends the voluntarist philosopher - by as much exercise of will: " He made of this work a real cult and brought into play, to achieve the wanted ideal, all energy and warmth of his soul of great teacher" (Gheorghe Ivănescu). "The most part of his works revolve around issues of Christian ethics. From his ethics we learn the idea that in each individual who comes into the world it is a light, in each neighbor is an earthling God. The only moral authority that must be recognized is of Christ" (Gheorghe Ivănescu, School seen by the light of the Foerster's concept, "Gazzette of the School", Nr . 3-4, Craiova, 1931). The idea will have been of inspired Enlightenment, but ends without the exegete to point, in a plea for a flat practice, according to ethical education of that time: "Thefts, murders, robberies, etc., as well other charity of daily life, from magazines and newspapers to be analyzed, reviewed and judged, because of them to draw one instruction, which will be strictly complied with". The distance between the glamour origin of human being and how he needs to recover the Christian calmness demonstrates afterward, that the balance of this doctrine results from the cultivation of extremes (Vlăduţescu, 2013d; Ionescu, 2008).

From the beginning, people were looking for signs and meanings in astral movement on canopy and were interested to know themselves, in terms of character. Are mentioned in a 1937 article in "Gazzette of the School", each outstanding contribution, Homer, Descartes - that puts order in any issue approaching, proclaiming rational demarches to knowledge of a phenomenon, Locke, Hume, Helvetius, Gall, Lavater (Kulczycki, 2012). A real gnoseology that open interdisciplinary bridges, forms the studies on these philosophers and educators, or other trendy, serially published, in Empirical methods section. Paradoxically, this column opens today subjects that are the favorite of popular magazines as "Formula AS", not the scientific and analytical depth. We discuss more scientific attention than perhaps it was appropriate, about phrenology and palmistry.

What is rare in such as items, the detail that fit these philosophers, whose name became eponymous for discipline that served them, in their family condition: "When Socrates was advised by friends to leave his wife because he was too nagging, he replied: I learn patience ", or that of the origin of philosophy, who would have been in the tradition of comparing moods, with elements of external nature. Montaigne, for example resemble the rich people in the principles with the wheat ear.

\section{THE GATE OF ANTIUTLITARIANISM}

Gheorghe Ivănescu admits many of Foerster's opinions, and for those which he would disavow: "It seems that Foerster would have faith that science works against life and morality", comes with tone of reconciliation on the theme: "science grows humility, sincerity, patience, etc.", still sustaining of the philosopher, that he issued such ideas with good intentions, faith in Christ recovery, through spiritual evolution, and not by admitting mechanical triumph over nature.

Gentle suggestion to the German philosopher is that if Socrates upheld, against popular opinion, to stay in a marriage where he was nagged by an inferior the wife, then why we can not accept the positive role of science in our lives, it must be one, no matter how small, even derived from shortcomings. For instance, frustration in front of the wonderments that makes a 
machine leads to accepting our limitations and recognize them becomes a form of wisdom (Strechie, 2008); Strechie, 2010). Neighbouring with serious products of the technology etc. has another good effect: various things are completed faster, to human remaining more time to meditate upon himself, to know himself better, in other terms. The blamed science (not of a sector, but science in general) thus favours one of dogmata points, that give more opportunities and wider as time, to exercises of "self-knowledge" (Ogonowska, 2012; Vlăduţescu, 2013d).

Regarding the role of the family in society, Foerster and Hegel are antithetical. First sees in family "a moral institution. The woman is a priestess of ideals", the second sees, "a legal institution. "Foerster puts "all hope in the next generation" in resolving the moral crisis; here is opposed to Nietzsche, himself leading the opinion, that "is hoping in a providential superman Kemal Pasha, Clemenceau".

Fr. Foerster seems modern in pedagogics domain, asserting "to give the student more freedom, but an orderly freedom". The current he belongs has the origin in pedagogy "of Rabelais, Montaigne, Rousseau", another opposite "prioritizes measures to exert a negative influence, that constrains any free expression of the individual" and is called the rigor current.

The editors of "Gazette of the School" were well informed, including Gheorghe Ivănescu. He writes: "this pedagogical optimistic opinion was advocated by Swedish writer Ellen Key, recently deceased". The other current "claims that man is evil by nature, so we must destroy the evil in him. Prominent representative of this trend is Paulsen "who" tells us that education today gives us moral and weak people, whereas the old gives us people resistant, active, learnt to struggle and to restrain evil tendencies. "

Foerster's pedagogical concepts, of pointing the subject are valued: "He wants to replace the work school, freedom school, social school etc., with the school which exclusively forms characters".

The second article about Fr. Foerster will appear as Foerster's doctrine, by Vasile Popa Măceşanu, teacher at the School of Application from Timişoara ("Gazzette of the School", Nr. 1-2, Craiova, 1939). The interest for the ideas of this thinker of the time was marked earlier of debates "Gazzette of the School", by appearing in History of Pedagogy, of a study, signed by Ilie Popescu Teiuşan.

The study Foerster's doctrine becomes an opportunity for Vasile Popa Macesanu, teacher at the School of Application Timişoara to vituperate the socialism: "Foerster is a social educator. Aside Natorp, Kerscheinsteiner and Durkheim, he has worked extensively with the problem of citizenship education. He met, however, a current that in the form in which it was designed, it was dangerous, the socialism". We are wondering what effects this article of and others similarly endured the subscriber Vasile Popa Macesanu, during the communist period, especially proletcultism.

Ilie Popescu Teiuşan decrypted the main concepts of this thinker fashionable then, in his History of Pedagogy.

Friedrich Foerster initiate his philosophical system, from those issues encountered everywhere, that he does not agree. He enounce mainly mechanization that abused the good privacy of the individuals, intimidateting their religious disposition: "the modern age civilization bears the seal of the mechanization" (Ilie Popescu Teiuşan, History of pedagogy, p.5), then moral causes that impoverished the moral side of culture and opened the utilitarianism gate: individualism, dilettantism, non religiosity and obviously, the socialism.

Individualism, born of rebellion conditions of the French Revolution, when personality was totally negated, generated adverse effects, since it does not bring anything good to the society. It consumed its sense. But people had grasped to take the current, the shade of infatuation, that began to isolate them from one another; instead of a friend to help them, they 
brought a machinery, a robot (the utility of the kitchen one, for example, not one of SF movies) to simplify their labor. Each individual has begun to accumulate, excessively, devices which, serving him, isolated him from the rest, of own vocations of inventiveness and industriousness. In society was necesary for more communication and taking things from their primary purpose, not from the standard required by the machinery. In this manner educator Foerster saw the things like.

The danger of the individualism is not received eventually, the individual revolt to the social order, but the personal opinion that it would be able to interfere in any matters that do not concern him, not to resolve them, but in order to offer a new opportunity to give lessons and to infatuate. Individualism encourages "individual impulses (Kulczycki, 2008; Kulczycki, 2012): self exalting confidence, willingness to do whatever he wants no matter whether it would be in antagonism with moral and social rules; denial of any value. He makes him to believe that he is able to blend into any problems, even moral, giving rise to what is called diletanteism, he uses the opportunity intruding into matters affecting financial gain driven by the dictum: the goal excuse the means, he carries away from the church and God. Jesus Christ has gone from his heart."

As far as we are concerned, we are reserved beside to this side of the criticism of individualism as providing for regulatory action, the antithesis between an authoritarian state and an individual with personality and powerful network action: "Individualism weakened man and downgraded dozens of centuries. But a salutary formula is useful for suppressing evil. What? Authoritarian state. The state whose central will to dominate individual wills to coordinate them and to put them into the service of his interests" (Vasile Popa Măceşanu,"Gazzette of the School", no. 1-2, 1939, p.5). However, if the individual has productive ideas and in the space to say of his business areas appear spiritual and physical recovery zones for other people, his employees for example, why to oppose him the state apparatus that will not determine maybe ever this possibility for people, there, at that level of society?

Another danger of individualism, seen by the German thinker, reaches revolt of the individual to the social order, namely the desire to finally set down to his house and to accept as favorable, due to the need for peace, the range of industrial products.

Dilettantism, exercised by upstarts from different areas, we should say, is in developing today, but as erosive as ever, it revolted especially those who had the feeling of their profession and who Friedrich Foerster represented them. Office holders, today, more than ever, given the membership of the party, come across the truly professional, giving superficial ideas, starting at party meetings. Mistake and offence of the society are not the orders itself, as scrupulosity to follow up their fulfillment (by individuals without professional skills, but with functions and the subscription up to date).

An unfortunate consequence of modern human devotion beside the machinery, of the belief that it is only useful mechanical environment and perhaps politically dilettantism, was the outbreak of World War II.

It was a fashion dictatorship which unfortunately lasted, at least in Eastern Europe until twenty-four years. We put value on the individual. Over the time, it has been demonstrated that only through culture he comes to understand and help to stage work, society, welfare of things. We disagree, however, with the alienation of church, observed trends (in the thirties) also by Foerster, but we are convinced of the role of serious culture near religious values. By knowledge almost all are resolved. At the same time, it seems exaggerated the state to be bound by the church: "The Church of Christ is the central that ensure the soundness and viability of the state" 
(Vasile Popa Măceşanu, "Gazzette of the School", Nr. 1-2, 1939, p.6). It is no need of citizenship to belief.

Themodern man is accused of ireligion: "man is possessed by ireligion", of the late thirties and perhaps contemporary, figure among the causes of the society decay. When you miss the faith target, harassed by doubt, of course there is nothing to do, no matter how much you try to lie to you, surrounded by auxiliary devices, that you are good and you are in progress. You can not find sense only in the small pleasures of the day, but who will claim mechanical interference from you (the individual), full of energy, to drain you of life and you do not get to enjoy his contemplation, in full harmony with you, regardless of the outside turmoil (Dascălu, 1986).

Foerster is in disagreement with aestheticism, about which states that "it is an attitude by usage, i.e. of cultivation". He has a judgment alike Titu Maiorescu and opposite to that imposed by Eugen Lovinescu: a well-written book is nothing if it will have not a central moral issue.

Romanian philosopher, Constantin Rădulescu-Motru, who went to college to sit for examination shod in peasant sandals, deployed consistent serials with the theme The school of the village. The title has a double meaning, either is necessary a greater involvement of school in rural life, or for anyone who wants to become somebody is required to have the village school, that is to be learned a conduct of public resort, based on a long tradition of decency (Vlăduț, 1998; Fras, 1996; Vlăduţescu, 2013e). He was a fervent collaborator and many of the magazines of Oltenia were based.

Today, maybe we are thinking that the top of Romanian village prosperity was reached in monarchical period, as, in the nineties of the last century, our grandparents acknowledged, who lived fully in that time (Vlăduţescu, Ciupercă, 2013). One minor household in the village, it grew so many birds that almost nowhere to put your foot. My grandfather, I found out, was disturbed in his affairs, by the spread birds, when downloading the yard carts, cursed not to see foot bird around and a good time, kept invective. Every day, for the house feed (family), was sacrified a chicken or a turkey. Of wheat and corn from the field, it earned good money. Such products had worth and it was deserved to sold them to market (Fras, 2012; Dima, Vlăduţescu, 2012; Păun M. G.). But Constantin Rădulescu-Motru finds the prosperity of the village, long before, in 1937, he saw thus: "How backward we are today! The old Romanian village is in full decay, its economical and political unity was destroyed. What made its strength once would not be able to be revived only by a school organized on peasant interests measure. The school of the village today but is a school out of peasant interests; it is a school of bourgeois imitation, town. "The blame should be "engineering mentality of the nineteenth century" in which were educated Romanian nationalists. They believed "with all their Western contemporaries, that the power of life of a political and cultural institution consists in its logical symmetry and consequently, that good laws can be copied by anyone exactly how to copy and making plans for a bridge". Engineering mentality would be counterproductive because it does not take into account the past: "In an old building is built not random, but are chosen sound walls and are built new walls, keeping to this the line of durable retaining of the old ones".

Romanian thinker, who had formed the opinion that "the national life of a people is supported by the continuity of its political and cultural institutions life", he denies the transformations undergone by village, whose ideal image of economically, would be: "Organization of the old village was for the life of Romanian people a real citadel. In it were housed original virtues of our peasantry. It was an organization that primarily, were reconciled technique of the collective work and technique of the individual work. Free peasants had individual ownership and entirety by kindred. The tributes were paid by the whole village, but by quota, i.e. on share of wealth of each. The owner cannot sell on his will, because the villagers, aligned after relatives, had the right to be preferred. The work was done by peasants, 
both jointly and on their own, to help with counting right. The cows were individually owned, their grazing property was hurly".

From point of view political and cultural, the village organization "indulged in a wide autonomy. The peasants had the administration and justice in their village, even the military organization was in the village (...). Although the church is bordered to the role of Christian tradition, and the school was reduced to the experience of the old and common sense, however there was a cultural production. We learn it in all schools as our national art itself. If we add to these manifestations of art, production in the industrial field, we have an icon almost complete of that was the old village organization: a household perfectly balanced, in the middle which peasantry found their food, clothing, political order and its cultural needs gratification in a complete autonomy" (Vlăduţescu, 2004; Vladutescu, 2006).

The blame for the dissolution of rural organization is "the bourgeois spirit that brought with them the last century nationalists (...). Through imitation, after West, the formerly alive village enters as a shadow in abstract territorial separations. The core of his collective work technique, proved so fruitful, is rejectable. The peasant is separated from the village unit to be made free enterprise, trader, homoeconomicus".

Constantin Rădulescu-Motru records that only school can return attributes and save traditional village, of those still exist, and a pivotal role in the spiritual rebirth of the inhabitants it is the teacher who in his turn, must be animated by a double conviction that "rich city is only rich villages connected city" and "school of the village has the aim to prepare the villagers children for a life of the village" (Iuhaş, 2012; Vlăduţescu, 2013h; Wendland, 2013).

The opening was also to America ca. In the views of the editors of the "Gazzette of the School", was John Dewey, leading representative of pragmatic philosophy, who applied the theory of mental activity to Experimental School, founded by him, The University Elementary School. Aside William James, John Dewey, the professor of "giant thinking of Columbia University in New York, is also the main driver of activists movement, in the matter of education. The active school concerns contemporary pedagogy "(Ilie Gruia, teacher at the School of Application from Târgu-Mureş, no. 11-12, 1937, "Gazzette of the School").

John Dewey delimits the ego of consciousness, considering it a lower class consciousness, a simply mean "of adaptation to the outside world". Consequently, the ego (which serves only this purpose, of node with the world) can be processed and dominated. It would be wrong to let us processed by own ego, when his role is so simple, a hook for hanging the world. Consciousness is what breaks down us, but after processing the facts and events in which we live. Consciousness connects us to our intimate past, that one that we judge in us and try to correct us depending on how we seem us beside of what we have done. Ego is dynamic, he draws us after him and hence he has to be schooled. "John Dewey's pedagogy could only be dynamic, to answer to the continuous activity of the ego" (Ilie Gruia, "Gazzette of the School", Nr. 11-12 / 1937, p.7).

Spontaneous needs, located at the bottom of the child soul, are categorized by John Dewey: "a) need to converse and communicate what he knows, b) need to investigate and find, c) need to fabricate and build d) need to express through art what he feels "(History of Pedagogy, P. Teiuşan, p. 233).

In general, the Dewey's pedagogy, exposed in his the main book, The school and the child, is "genetic, functional and social" (Ed. Claparede). He is not "utilitarian in the sense of Kerschensteiner, aiming at learning of a craft" (M. Dragomir).

John Dewey "strikes convinced in intellectually education of the time, demanding integration of the child in life: is aiming the system of subdivision of school work, showing that the child's soul is only spontaneity and interest" (Dragomir, "Gazzette of the School"). 


\section{CONCLUSION}

These articles provide before views on philosophers labor of universal value, expressed in the time in which they lived. Otherwise, it can be distinguished between present and posthumous images taken by them. The press from Oltenia, during 1920-1940, was marked by three dogmata: antiutilitarianism illustrated by Fr. Foerster, the Politische Ethik und politische Pädagogik (1920) Romanists (positively, of fixing in tradition), represented in particular by Constantin Rădulescu-Motru by Romanism. Catechism of a new spirituality (1936) and The Psychology of the Romanian people (1937); third dogma, of functionalist psychology, is supported and promoted by John Dewey, by Psychology (1886) and The Reflex Arc Concept of Psychology (1896).

Noticeable decreases in time made them perishable.

\section{References}

[1] Borowski A. (a), International Letters of Social and Humanistic Sciences 4 (2013) 70-74.

[2] Ionescu D. (a), Journalism and Mass Communication 3(8) (2013) 528-531.

[3] Ionescu D. (b), Global Research Analysis 2(8) (2013) 17-24.

[4] Dima, Ioan Constantin; Vlăduţescu, Ştefan (2012). Persuasion elements used in logistical negotiation: Persuasive logistical negotiation. Saarbrucken: LAP Lambert Academic Publishing.

[5] Borowski A. (b), International Letters of Social and Humanistic Sciences 6 (2013) 86-90.

[6] Păun M. G., International Letters of Social and Humanistic Sciences 6 (2014) 42-48.

[7] Vladutescu Stefan. (2006). Comunicare jurnalistica negative. Editura Academiei Romane, Bucuresti.

[8] Kulczycki E. (2012). Teoretyzowanie komunikacji, Poznań.

[9] Borowski A. (c), International Letters of Social and Humanistic Sciences 7 (2013) 113-118.

[10] Vlăduţescu Ştefan (2004). Argumentaţia şi demonstraţia, ca moduri de impunere. Craiova: Editura Sitech.

[11] Kulczycki E. (2008). Status komunikologii - przyczynek do dyskusji. Poznań.

[12] Vlăduţescu Ştefan, International Letters of Social and Humanistic Sciences 6 (2014) 49-54.

[13] Wendland M., Dialogue and Universalism 1 (2013) 51-63.

[14] Vlăduţescu Ştefan (a), International Journal of Education and Research 1(11) (2013).

[15] Fras J. (1996). Political Discourse as an Expression of the Polish Political Culture after 1989. The Political Culture of Poland in Transition, Wroclaw, Wydawnictwo Uniwersytetu Wroclawskiego, 151-62.

[16] Vlăduţescu Ştefan (b), International Journal of Education and Research 1(12) (2013). 
[17] Ogonowska A. (2012). Kultura, komunikacja i kompetencja wizualna w kontekście wybranych zagadnień współczesnej humanistyki. W: Kulczycki, E., Wendland, M. (red.) Komunikologia. Teoria i praktyka komunikacji. Poznań: Wydawnictwo Naukowe Instytutu Filozofii UAM, 53-67.

[18] Vlăduțescu, Ş. (d), American International Journal of Contemporary Research 3(10) (2013).

[19] Ionescu Alice (2008). Modalisateurs illocutoires et argumentation. Craiova: Editura.

[20] Vlăduţescu Ştefan (e), European Scientific Journal 9 (2013).

[21] Strechie M. (2008). Condiţia femeii în cadrul familiei romane de origine ecvestră în perioada Principatului. Universitaria.

[22] Vlăduţescu Ştefan (f), Jokull Journal 63(8) (2013) 186-197.

[23] Kulczycki Emanuel, Studia Humanistyczne AGH 11/1 (2012) 21-36.

[24] Dascălu C. (1986). Dialectica limbajului poetic. Ed. Facla.

[25] Vlăduţescu, Ştefan (g), Jokull Journal 63(9) (2013) 301-318.

[26] Fras J. (2012). Podstawy identyfikacjii typologii wypowiedzi w mediach masowych. $W$ : Kulczycki, E., Wendland, M.(red.). Komunikologia. Teoria i praktyka komunikacji. Poznań: Wydawnictwo Naukowe Instytutu Filozofii UAM, 13-29.

[27] Vladut Dumitru (1998). Figuri sintactice repetitiv-adjunctive în stilul stiinţific. Filologie, 25.

[28] Iuhaş F. (2012). Univers ceremonial şi mass media. Bucureşti: Editura Ars Docendi.

[29] Vlăduţescu, Ştefan; Ciupercă, Ella Magdalena (2013). Next Flood Level of Communication: Social Networks. Aachen: Shaker Verlag.

[30] Dima Ioan Constantin, Vlăduţescu Ştefan, European Journal of Business and Social Sciences 1(6) (2012) 27-33.

[31] Strechie Mădălina (2010). O istorie a mentalităţilor şi a mijloacelor de comunicare din preistorie şi antichitate. Craiova: Editura Universitaria.

[32] Vlăduțescu, Ștefan (h), International Journal of Management Sciences and Business Research 2(8) (2013) 1-9. 